\title{
REFLECTIONS ON INTERNATIONAL NARRATIVE RESEARCH ON THE EXAMPLE OF THE TALE OF THE THREE ORANGES
}

\section{Christine Shojaei Kawan}

\begin{abstract}
The Tale of the Three Oranges, also known in different cultures as L'amour des trois oranges, As tres cidras do amor, La brutta saracina, La mora tuerta, is one of the most favourite fairy tales. The tale can be characterised by a remarkably long text history, it has been recorded in hundreds of variants, and studied by means of the historic-geographic method. On the example of The Tale of the Three Oranges the author has pointed out several barriers and problematic areas in international legend research.
\end{abstract}

Keywords: fairy tale, historic-geographic method, literary variants, context, narrative sociology

The Tale of the Three Oranges - also known as L'amour des trios oranges or As tres cidras do amor, but also as La brutta saracina, La mora tuerta - is one of the most favourite fairytales in the Mediterranean region and in the Orient. The tale is somewhat less known in Europe, since it is not included in Grimms' Fairy Tales and other popular fairy tale anthologies. The story is about a Prince, who finds - often after a long adventurous quest - three beautiful maidens inside three oranges, lemons or other magic fruits. As soon as the Prince manages to win the third as his bride, he becomes careless and leaves the girl alone to bring her proper royal clothes, carriage and retinue. He leaves his bride waiting on top of a tree, hanging over a pond, a spring or a well. There comes an exceptionally ugly dark-skinned slave-girl to scoop water, sees the reflection of the Orange Girl in the water, considers the reflection her own, and angrily breaks her mug - no more work from now on! Hearing the Orange Princess laughing in the treetop, the slave-girl realises that she has made a mistake and in a blink of the eye turns from an ignorant black slave girl into a person of sophisticated guile. Having heard the Orange Princess' story, she devises a cunning plan to deceive the Prince by assuming the identity of the princess. She either pricks the Princess' head with a needle upon which the Princess transforms into a dove, or pushes her into the water upon 
which the victim undergoes a series of transformations. Regardless of all the troubles the Orange Princess will eventually reassume human shape and can wed the prince.

This fairy tale text has a remarkable history. Hundreds of variants of this story have been recorded in the area between Portugal and Persia; Walter Anderson, the founder of the historic-geographical method, has studied the folktale type for years, ${ }^{1}$ and Christine Goldberg has treated it in the 1997 type monograph based on her improved version of the classical method. This folktale enables to demonstrate the types of problems and obstructions encountered in folk narrative research.

\section{ON THE HISTORIC-GEOGRAPHIC METHOD}

Narrative research, and Märchen research in particular, started with the collection of material, the attempt to protect from falling into oblivion as many past accounts, which according to the 19th century thought originated largely in some mythical prehistoric times, and save as much of what was worth saving as possible "at the last minute". (These activities have been continued up to the present day). The comparative notes of the Grimm Brothers to their fairy tale anthology indicate that folklore scholars discovered relatively soon that folk texts are neither unique phenomena nor can they be attributed to one particular ethnic group: some tale types occur in numerous variations and have spread in different countries. The accumulation of increasingly larger amounts of material raised the issue of organisation and systematisation of the texts. For this purpose various experiments were conducted. A breakthrough came with the Finnish scholar Antti Aarne's method, which was published in a modest booklet entitled Verzeichnis der Märchentypen mit Hülfe von Fachgenosse in 1910, which from then on became the standard-setter in international folk narrative research. Since Aarne's method was based on the Finnish narrative material and predominantly on Scandinavian folklore studies, the standards were also mostly Finnish and Scandinavian, respectively. The absence of The Three Oranges, one of the most favourite miracle tales collected from very many countries, from the Aarne type register could be explained simply by the fact that it was not known in the Finnish tradition. In 1928 Stith Thompson included The Three 


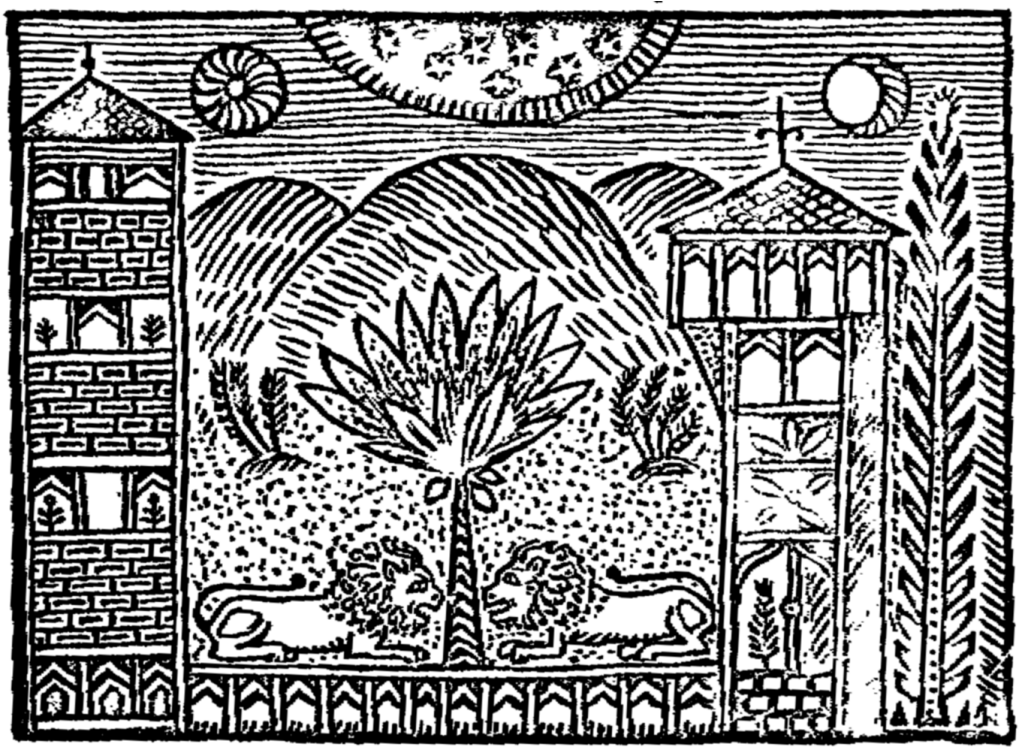

Picture 1. An orange or apple tree guarded by two lions (Megas, Hellenika Paramythia 1).

Oranges in his additions to Aarne's considerably extended type register under type 408. Thompson described the fairy tale, which from then became a fixed tale type, relying on the version included in the famous Norwegian Folk Tales by Asbjørnsen and Moe. The text (which surprisingly does not differ considerably from the Mediterranean lore) has remained the only variant of the type AT 408 in Norwegian lore - and it is not known where the fruit seller in Oslo, from whom the tale was recorded, had heard it. Only in 1961, in Thompson's second addition to Aarne's type register, Anderson presented a more detailed structure description based on his in-depth knowledge of the material, which, in turn, was modified by Goldberg who defined two subtypes in 1997.

After the establishment of organisational principles at the beginning of the 20th century, scholars began to conduct studies based on the defined types. Studies focused on content analysis, including a detailed description of single motifs, determination of origin and dissemination routes and reconstructing the original form. The aim was to achieve satisfactory results by gathering as extensive docu- 
mentation as possible. Anderson's introduction to the variant analysis, which he called the "Chinese mixed redactions" of The Three Oranges tale reflects this devoted aspiration towards perfection:

These two mixed redactions (AT 510 A+408 and AT 433 A+408) form the most difficult part of my task and have caused much problems and disappointment: not so much because the scantiness of the material at my disposal / --- /, but because, regardless of my greatest efforts, considerable financial resources and the self-denying work of several scholars (particularly Isidor Levin in St. Petersburg), I have not managed to acquire ALL the existing copies of these two tale redactions. ${ }^{2}$

Seeking perfection is often accompanied with a tendency to include analogous but non-characteristic material, like the previously mentioned "Chinese mixed redactions" of The Three Oranges tale, including variants of Cinderella and Snake Husband fairy tales (the latter being one of the many tales about animal groom or spouse), where the female protagonist falls victim to murder plotted by her sister or stepmother and then undergoes several transformations. Metamorphoses, forming a relatively extensive part of the text, are the only feature in which these tales coincide with The Tale of the Three Oranges. Wolfram Eberhard, the famous Sinologist and narratologist, has claimed that the first part of The Tale of the Three Oranges has been altered, as several of its features would be unacceptable, even inconceivable in the Chinese tradition. It would be unthinkable to mediate the Prince's affair to a Chinese farmer in this form. A Chinese man would either marry a girl chosen for him by his parents or a concubine, but would never bring a bride to his home. According to the tradition it is rather the bride's relatives who bring her to her soon-to-be-husband (Eberhard 1951: 79 and following, esp. 81). This, again, indicates to the issue of the relationship of fairy tales with reality. Eberhard's next comment is even more surprising: "No Chinese girl would climb a tree and stay there for the night." This would not be very common to the young ladies in Spain or Italy either - but in these two countries the tale of three oranges or lemons has always been and still is very popular. The sc. "Chinese mixed redactions" were therefore categorised under type AT 408 only because both shared the same final episode of multiple transformations, which characteristic sequence 'animal tree - chip' appeared already in Old Egyptian brother fairy tales 
(approx. 13th century BC). Instead of searching for directly related links, it would be more reasonable to assume that it is a narrative reconstruction of a popular mythological motif - namely, the idea of soul travel, which is most popular in South and East Asia, but also in Ancient Greek. If we analyse the multiple transformations of the female protagonist in the light of this narrative motif - widely spread and known in Asia and not directly related to The Three Oranges and treat the "Chinese mixed redactions" as either independent tale types or the elaborations of Cinderella and Snake Husband tales, then the number of variants of The Three Oranges tale is smaller, but the tale type as such becomes more homogeneous and coherent.

The main aims of the historic-geographic method - the ascertainment of the origin and distribution routes of tale types, studied in monographs, and also the reconstruction of the original form - still attract interest in narrative research. The reason why these objectives have become secondary is the lack of convincing results so far. In addition to other shortcomings that folklore studies have to tackle, inadequacies are also conditioned by the type of the text corpus namely, the 19th and 20th century oral texts, which may be based on even earlier oral narratives, and a relatively small number of literary variants from widely different eras that go back to the ancient times. The international spread of the texts has introduced problems like the varying intensity of collection in different countries, the different degree of authenticity, etc. Since so much had remained unclear, the material was approached through mechanical methods, leading to speculative, often even contradictory results. Anderson's reflections on the date of origin of some details of The Three Oranges tale illustrate it nicely:

"Usually, the nymphs ask the prince some water while they step out of the orange fruit, but this narrative motif may vary. In Spanish and Catalan, but also in French, Italian, Croatian and Slovenian texts the nymphs ask for some water, for a comb and a towel. Anderson (s.a.: 329) concludes that this motif cannot be very old, since it is not known in South America. From the viewpoint of logic this may even be possible, but it depends on preliminary assumptions; unlike natural scientists, narrative researchers cannot conduct experimental studies to test their conclusions (even though Anderson himself seriously sought to develop experimental meth- 
ods in folklore studies). This particular case may refer to the relations between the Latin American variants of the tale and the Iberian tradition, though nothing is known about the form and time of transmittance. The South-American variants may very well be reduced forms, since they generally appear to be shorter and less artistic than the Iberian texts."

The fact that "the girls, who stepped out of the two first fruits, died" is for Anderson "an undoubtedly original feature, very characteristic to our fairy tale" (Anderson s.a.: 334). As the hero disregards the instructions, according to which he is allowed to open the fruits only after arriving home or at a spring, Anderson accuses him of involuntary manslaughter, but then proceeds:

"It is therefore understandable why many narrators have modified the original tale, by having the two first girls not die but disappear,"

and presents a long list of variants that have undergone such modification. ${ }^{3}$ All in all it appears that the number of texts telling about the Orange Girl's death is almost equal to the number of texts, where they disappear into thin air, fly away as birds, or disappear back to their orange or to the tree, etc. Thus it remains unclear why Anderson has thought the first form more original than the other, especially since the fact that the third fairy girl, the female protagonist, is surprisingly resistant to all murder attempts - it is literally impossible to kill her. Anderson himself demonstrates the unstable logic of the historic-geographic method in his description of a motif detail from the reflection episode.

"On the other hand, the line of plot, where the ugly woman is made to stand in front of the mirror to prove her how irrational her claims of her beauty are /---/, is highly intriguing. The number of variants is very modest indeed and at first glance the detail may be seen as a random modern addition; but is it present already (before the year 516) in one of two Ancient Indian variants on the reflection motif through a misinterpreted independent anecdote. /---/" (Anderson ibid: 415, ff).

The tale under discussion is a Chinese elaboration of an Indian Buddhist tale. As here the presence of the old literary narrative is obvious, Anderson cannot rely on a huge number of variants, which 
he had otherwise used as axiomatic evidence; regardless of all, he does not question the ordinary method of proof.

Due to the geographical location of the variants, Anderson believed that The Three Oranges tale originated in Persia (Anderson 1959: 5). This assumption seems acceptable, but, again, cannot be proved. Forty years later Goldberg, who appears less interested in the traditional problems with the historic-geographic method, is more careful with her conclusions. As to the form of subtype A defined by her (in which the heroine undergoes several transformations), Goldberg claims that the individual episodes of this tale "were joined somewhere in the Mediterranean region or in the Middle East, as far east as Persia or as far west as Italy, to become what can be considered the archetype of AT 408, AT 408 A" (Goldberg 1997: 216). The assumption that the tale type has emerged in its main distribution area can hardly be erroneous, though the proposition of such a wide geographical territory does not seem to have much informational value either. Goldberg appears to be particularly puzzled over the reasoning of the distribution of subtype $B$ (i.e. variants, where the heroine transforms into a dove by a prick of a needle): she cannot understand how has it been possible to overlook or purposefully leave out such an extensive part - the recurrent metamorphoses and the usually following episode, where the girl transforms back from her last form of existence, the wooden chip, into a human, and secretly keeps an old woman's house tidy. In conclusion, Goldberg construed a complicated explanation, according to which subtype B may have emerged from independent single episodes (ibid: 216, see also 83 and 103). A more likely assumption would be that in the countries where the oriental idea of soul travel was not known, the girl's multiple metamorphoses were adjusted to the requirements of the European miracle tale: the metamorphoses were substituted with a single transformation, i.e. a magical activity. In Greek tradition, where the transmigration of souls dating back to the ancient times were known through the Pythagorians and the Orphics, The Tale of the Three Oranges still includes recurrent metamorphoses; further west, in Italy, both forms occur, whereas the simple transformation into a dove seems to dominate. Only the latter form occurs on the Iberian Peninsula. The second subtype cannot therefore have emerged by coincidence, by overlooking something or purposeful omitting, but needs to be understood as the manifestation of a different world view. 


\section{LITERARY VARIANTS}

Narrative researchers who prioritise literary texts over oral texts, or who derive the latter from the former, often presume that the first literary variant of a tale type is also the earliest. The first literary version of The Three Oranges is the ninth story of the fifth tale in the famous Pentamerone by Giambattista Basile (written during 1620-1630 and published in Naples during 1634-1636), entitled Le tre cetre. In Basile's version, a Moorish girl pricks the tale's heroine with a needle in her temple and the heroine turns into a dove; after the Moorish girl has had the dove killed, a citrus tree with three beautiful lemons grows from its feathers. The King cuts the lemons open, one after another - just like in the beginning of the tale -, and the first two girls flee from him. The cyclic succession of transformation and the idea of eternal return and renewal during the process is very impressive in the tale; in folklore it has not had significant influence, which also explains why Basile's version can not be the source of tale type AT 408. The most remarkable variant in this context is Felix Karlinger's "translation" (Karlinger 1973: no. 20), where the heroine from a chestnut later re-emerges stepping out of the chestnut, which has fallen from the chestnut tree that grew on the slain dove's drop of blood; this is an arbitrary alteration, which may have been prompted by the influence of Basile's fairytale, since in the original version, a dialectal text from Abruzzi (Finamore 1885: no 54) the heroine first appears from a chestnut, but at the end of the story she emerges from a pomegranate. Translators have to tackle the difficulty with fairy tale verses: the translations of verses characteristic of The Three Oranges, as well as of the Mediterranean tradition in general, have rarely been equal to the original. But it is difficult to explain why Karlinger has inserted poor verse passages where traditionally there were rhymes or rhymed dialogues - his textual variant does not include typical verses. ${ }^{4}$ This demonstrates how publishers and translators, regardless of all their efforts towards authenticity, handle Märchen texts, how the style and contents of stories are tried to be corrected, levelled and adjusted to the expectations of the readers of standard taste.

About 40 years after Basile's Pentamerone, Lorenzo Lippi's Malmantile racquistato was posthumously published in Florence in 

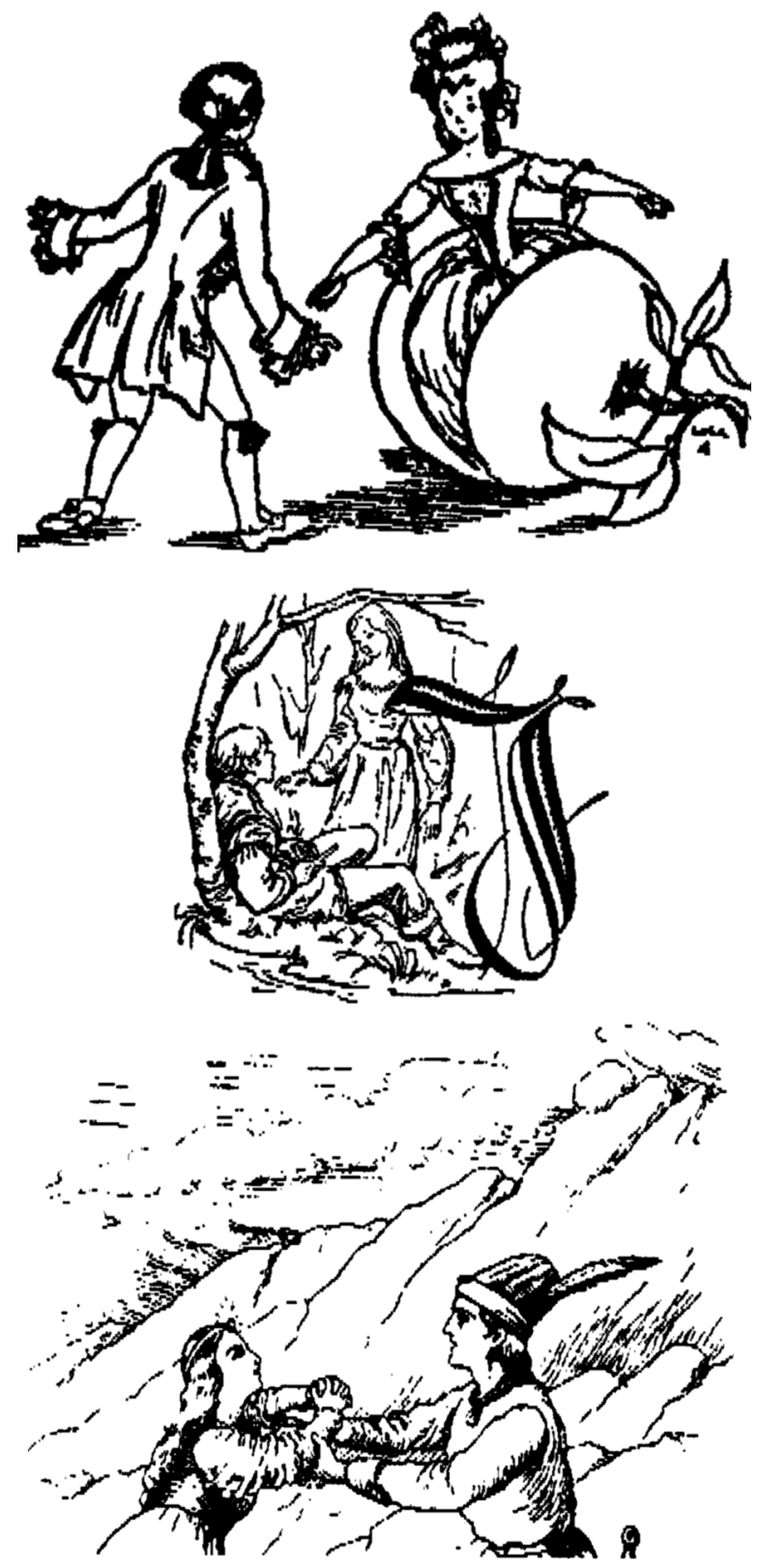

Pictures 2-4. Scenes depicting Orange (lemon) Girl emerging from the fruit. 
1676. The most famous example of this genre is Tasso's Gerusalemme liberate. Due to the numerous references to classical and contemporary literature, associations to his era, and the use of "florencisms" and "tuscanisms", Lippi's poem is virtually illegible; the book was therefore supplemented with three successive and complementary publications of comments. In his epic Lippi used some modified popular tale plots that Benedetto Croce believed to originate from Basile's collection, even though only one Lippi's tale is clearly connected to Pentamerone (Shojaei Kawan 1996). Lippi's third fairytale, the story of Nardino and Brunetto (Malmantile 7: 27-105) is a variant of The Three Oranges (contaminating with the tale Faithful John) and is treated as such in the studies by Anderson and Goldberg, regardless of Lippi's loose interpretation of fairytale plots (or, perhaps, fairytale motifs?). Since Lippi's "variant" is not mentioned in secondary literature, let me sum up the more important content elements.

The tale tells of two brothers who love each other dearly. Nardino cuts his finger at the table and upon the sight of blood on his napkin is seized by insatiable desire for a woman who is as red as blood and as white as the cloth. Brunetto sets off to look for a suitable bride for his brother. ${ }^{5}$ In savage Magorto's garden Brunetto finds a watermelon (the fruit is also mentioned in some variants of The Three Oranges) and following previously given advice, Brunetto does not give the girl from the fruit anything to drink. (This follows a farcical episode, where Brunetto frees hermit Pigolone from the bag, where Magorto had confined him, and puts a dog in the bag instead, who will be later brutally beaten by Magorto.) Magorto fails to catch the escapees and curses the whole Brunetto's household: so that noone would be able to stop crying. Nardino is happy with his bride, but believes that the girl has not come to him voluntarily and is therefore unhappy. Brunetto reconciles the young couple, but the crying would not stop. Finally Magorto realises that his daughter has found a perfect match and cures the people from incessant crying with some tomatoes from his garden.

Lippi relies on traditional motifs as well as Basile's tale, but digresses from them increasingly. Then - is his tale a parody to fairy tales or a song of praise to tomato (which had reached Europe in the early 16 th century and which berries were at first believed to 
be poisonous)? In any case, it is not a tale variant in the traditional sense of the word, but rather evidence to the popular Tuscan tradition, which may also be inferred from the mentioning of the miraculous watermelon.

Unfortunately I will not be able to analyse all the variants of The Three Oranges $;^{6}$ of the literary adaptations, though, I would like to mention the influential theatrical fable L'amore delle tre melarance by Carlo Gozzi. This improvisational commedia dell'arte play (which is also a fairy tale parody and has reached us in the form of a commented table of contents) was effectively used by Gozzi in his counterarguments to Goldoni's and Chirari's innovative ideas. Literary theorists usually consider Basile's Tre cetre as the source of Gozzi's play; Angelo Fabrizi, however, who compared the literary motifs with numerous variants from oral Italian narrative tradition, managed to prove that Gozzi's work belongs to a different branch of tradition than Basile's variants; and while Gozzi has mentioned that his other works rely on Basile's and Sarnelli's work and on the French and Oriental fairytales, he has recurrently emphasised the plain origin of L'amore delle tre melarance - namely, according to him it is a well known children's fairytale (la più vile fra le fole che si narrano a' ragazzi). Already in the prologue the readers are asked to go back to the time when they were sitting by the fire with their grandmother (Fabrizi 1972). In the 20th century Sergey Prokofiev revived Gozzi's play with his opera The Love for Three Oranges (1921).

\section{THE CONTEXT AND SOCIOLOGY OF NARRATIVE TRADITION}

One of the main objectives of modern narrative research is the observation of narrative tradition in its live environment. The Russian school pioneered in the field in the early 20 th century. The sc. biology or sociology of narrative tradition focused on narrator's personality, repertoire, worldview and the social environment as a whole; later the focus was shifted to the aspects of function, performance, communication, reception and gender specification. There are excellent research works on all these areas of study, but the observation of the number of variants of specific tale types in these con- 
texts has proven problematic. Usually the problems occur due to the lack of information, but in modern research these issues ought to be addressed, at least to some extent.

Although registering the names of informants has become a norm in fieldwork, the names of narrators are known only for 52 out of nearly 200 variants of The Three Oranges; 37 of them are women and 15 are men. One of the narrators is the Hungarian master narrator Lajos Ámi, who is the subject of several studies. It would be inconsiderate to conclude from this information that the fairytale has been narrated by women, rather than by men; such distinction may apply to Spain, Catalonia and Latin America, as from these countries we have a considerable amount of data (15 female and 3 male narrators).

In the latter cases subtype B has been narrated without exception (i.e. one-time transformation of the girl into a dove); the episode of searching for miracle fruits is generally presented very briefly or is omitted altogether. The further east, the more fantastic and detailed the descriptions of protagonist's adventures become: the hero has to overcome life-threatening obstacles, survive encounters with dangerous supernatural creatures or personified elemental forces. The account of the adventurous quest may take even more space in the tale than the actual Three Oranges tale. Does the creation of

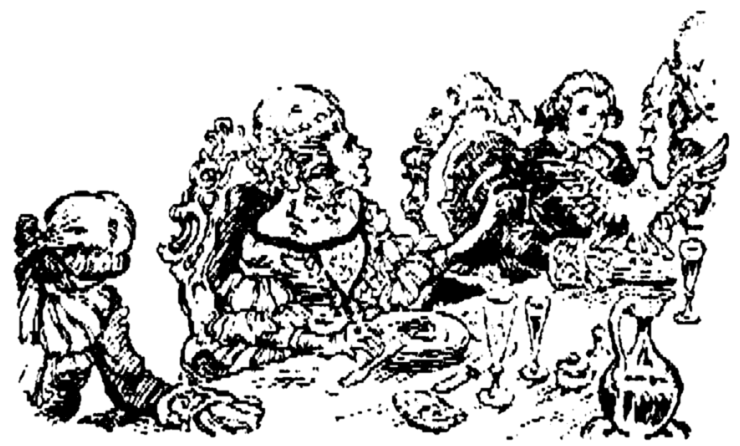

Picture 5. The princess as a dove on the royal dinner table. 
the male protagonist's role, the stylisation of a generally rather passive character into a dynamic figure in the narrative, which is otherwise dominated by two female characters, suggest that the text belongs predominantly to the repertoire of male narrators, or that it is addressed mainly to the audience consisting of men (or perhaps even men and children)? Anderson is certain that "such episodes describing the obstacles were part of the original orange tale text", and considers the variants which lack these episodes as "clearly incomplete texts" (Anderson s.a.: 214); Goldberg tends to believe that the masculine adventurous part of the text may be omissible (Goldberg 1997: 123; $111 \mathrm{ff),} \mathrm{and} \mathrm{I} \mathrm{agree.}$

It seems that the tale's function as a children's fairy tale has been suggested only in Gozzi's variant, though it is obvious that the texts are more suitable for an audience of children rather than a mixed audience. But would it be possible that The Three Oranges tale had an erotic undertone? Anderson repeatedly mentions an episode, which he thinks has "a consequential constitutive meaning" and which attributes the tale "the characteristic sensual-poetic charm" (Anderson s.a.: 275-280, 341, 467 ff., 703) - namely, the fact that "the Orange Girl emerged from the fruits in full nudity" (Ibid: 275). ${ }^{7}$ Anderson believes that the motif, which he considers original, "has been gradually suppressed or at least mollified by narrators, collectors and publishers"; as to Theophile Braga, for example, he has been able to discover analogous fabrication (Ibid: 277). This is why the Orange Girl is sometimes depicted as clad in sumptuous clothes. The argument that the girl could cover her body with her long hair is presented in order to emphasise her exceptional beauty rather than for the purpose of decency. In numerous variants it is said that the girl was naked; her nudity may also be inferred from the course of events, for example, when the prince covers the girl with his coat and leaves to bring her clothes - Anderson himself mentions these facts. Thus we may agree that the issue of fabrications was not as bad as Anderson claimed it to be. But the question - what happens when the naked girl emerges from her orange - is rather intriguing. Texts do not reveal much about it, though hugs, kisses and pledges of love are often mentioned. According to Anderson, the course of events in the original form was the following: 
"The Prince /---/ opens the third orange at the spring. Now he can give the third Orange Girl - the most beautiful of the threesome water to drink and the girl stays alive. The man expresses his love for the girl and promised to marry her, but since she is naked, he cannot just take her with him." (Ibid: $353 \mathrm{ff).}$

The texts do include formal marriage proposals, but are these "authentic" forms or the social norms of the 19th or 20th century values? Some variants mention - although passingly - something altogether different. According to a Spanish folktale, for instance, the Prince lifted the girl on horseback and rode off, but the horse grew tired and the Prince decided to leave the girl waiting at a spring. But before that, during their journey, the woman had already given birth to a child (Camarena Laucirica 1984: no. 74). The previous text becomes clearer if we observe it in the context of these variants, where the young couple does not go directly to the castle, but live together until the child is born. Only then the Prince leaves to tell the news to his parents and then bring his wife and child home (Larrea Palacín 1952: no. 55; Llano Roza de Ampudia 1925: no. 3). This raises various speculations: on the one hand it alludes to the kings and princes who had lovers outside their court; on the other hand it refers to the rural custom of marrying only after the bride was with child. One remarkable detail, which can be found in various Spanish variants (Jiménes Romero 1990: no. 79; Sánches Pérez 1942: no. 75; Espinosa 1946: no. 47) may, in fact, have emerged as a consequence to suppressing the previously-discussed episode. In order to keep the child, who has its own role in the story's plot (where the dove asks the gardener for news of the child in verse), it was attributed to the princess from the very beginning and the Princess was depicted - analogously to Virgin Mary - as having emerged from the orange with a child in her hands.

\section{THE OUTER AND INNER WORLD OF CHARACTERS}

Narrative researcher, who describes (at least within the framework of type analysis) a tale character, always describes it both collectively and individually, just like every variant is a combination of general type specifics and individual features. The emergence of certain discrepancies, however, is unavoidable. The female protago- 
nist of The Three Oranges is usually a magical creature, a nymph, or sometimes a girl, who is cursed into the fruit and will be saved by the Prince. She stands out among other characters for her beauty, while her antagonist stands out for her ugliness. So the two characters symbolise good and evil, which corresponds to the general character scheme of women in fairytales. The adversary of the beauty personifies the traditional conception of enemy: in Spain, Portugal, Italy, as well as in Turkey and Persia, it is an African girl (on the Iberian Peninsula mostly a Moorish, in Italy a Saracenic girl), in the Balkans it is a Gypsy girl, while in Greece and Malta sometimes a Turkish girl. The character may also be demonised to a witch, and may be called a Moorish or a Gypsy witch. The antagonist is a somewhat contradictory character: regardless of her naïveté and her poor grasp of reality in the reflection episode, she will later win her place under the sun through cunning scheming. She invents a clever answer to explain her change of appearance, by evoking guilt in the Prince, and she also recognises the protagonist of the tale in all her transformations. Both the protagonist and the antagonist are strong characters - the evil woman defends her position and tries to eliminate the heroine by every possible means, to which the protagonist responds not only with passive resistance (with her incredible ability to survive and reappearances), but also by employing her own arsenal. Thus it happens that the rosebush scratches the false queen's face (Megas 1965: no.30), the orange tree almost crushes her with its fruits (Boulenger 1935: 21-39), and the dove soils her food (Sánchez Pérez 1942: no. 75).

The weakest and probably the most pathetic role in the tale is that of the hero, the King or the Prince. Anderson writes:

"The hero is extremely dismayed and deeply frustrated of the alleged change of his bride's appearance /---/ (Anderson s.a.:491) The hero generally remains deeply unhappy and melancholy after the wedding, though in some variants gets used to his fake wife and is happy with her." (Anderson s.a.: 496).

Commenting on that, Goldberg (1997: 225) points to a well-known argument, according to which the feelings of the tale characters are described indirectly, through the action. Goldberg also confirms that she has not found a single variant in favour of Anderson's claim as if the wedding had triggered overall derision and mockery and 
the Prince had been inconsolable. "Usually characters simply get married or are expected to get married soon." Goldberg's viewpoint agrees with the general view of narrative research, influenced by Max Lüthi's theory of schematicism:

"In fairy tales feelings and qualities are rarely mentioned for their own sake or for creating a suitable atmosphere. These are mentioned when they happen to have some impact on the course of action. And even then these are not gladly spoken of."

Or:

"No reference is made to this inner emotional life; because the fairytale presents us typical characters, not human beings with living inner world.” (Lüthi 1974: 15 ff).

Could Anderson, then, have invented the character of a sad Prince? The following sequence of randomly selected texts will indicate how the narrators of The Three Oranges have approached the Prince's problem from the psychological aspect:

"The Prince was ashamed to present her to his parents like this, so he wrapped her up and lifted her to the carriage and drove to the castle and kept her hidden in a room /---/ and he worked hard at making the girl's skin white again. /--- / And the Prince became deeply melancholic and thought: "Did I put my life at stake with such efforts for some Moorish girl? What should I do, if she will never become white again?” (Megas 1965: no. 30).

"But he, no doubt, was particularly happy about it, because he spent days and nights watching his fish or riding on horseback with his friends." (Boulenger 1965: no. 30).

"He hesitated and having thought it over for a few hours, his uncertainty did not diminish”. (Mason 1925: 546).

"/---/ he felt frustrated for his friends, who asked whether the reason was worth inviting them over".( ibid.)

"From this day he was unhappy. He remained pensive and sad for the rest of the journey." (Seignolle 1946: no. 12). 
"Aziz told his father the story and his voice trembled with bitterness and fury. The king was deeply distressed and withdrew to his room, ordering to postpone the wedding." (Assaf \& Assaf 1978: no. 4).

"But everybody was laughing behind his back /--- / that such a mighty, young and handsome king had married such an old and ugly woman /---/. The King was not laughing, of course, he was worried and time and again he had to ask himself, whether his repulsive wife will once turn into a pretty maiden again. When they stepped out of the church, he looked into the eyes of his new mistress, but she remained as old and ugly as before. The King grew sad, but did not loose his hope." (Jech 1961: no. 14).

"What was he supposed to do? He had to take the old woman's ugly daughter, but he did not marry her. He was as sad as before, even sadder. He confined himself in a lonely chamber and shut everyone out."(Jech 1984: no. 23).

The above examples inspire the question whether the descriptions of Prince's emotions are exceptional or should the Märchen genre be reviewed in this aspect and the decisions on the features of form of this "Grimm genre", so convincing in its simplicity, which the Grimm Brothers' anthology had had a major impact, rethought? The Three Oranges tale includes another character, whose emotions are presented very intensely - namely, the Black Impostor, who represents the evil forces is a way which is not merely "schematical". The dynamic force behind her actions is the immense rage concentrated within an unjustly suffering person. From some point on she refuses to be a slave and in blind fury starts destroying everything that gets in her way - her cup, her hose, later also the Orange Girl's metamorphoses. In contrast, the colourful scenes, which in their poetic form describe the forming affection between the Orange Girl and the Prince, and parallelly the Orange Princess' aversion towards her adversary, are clearly stylised - e.g. the rosebush that leans towards the Prince, but scratches the fake bride's face; the dove, which allows the Prince to pat it and feeds on his plate, but defecates the food of her adversary. For the course of action these symbolic emotional scenes are completely unnecessary - the purpose of these episodes is to create a suitable atmosphere. The same applies to formula-like songs, where the dove wails 
over its longing and solitude. These very scenes, these songs define the mood of The Tale of the Three Oranges, the fairytale of feelings and love.

\section{Acknowledgements}

The article is based on Walter Anderson's analysis of the nearly 500 variants of AT tale type 408 (Die drei Orangen. Manuscript in the Archives of Enzyklopädie des Märchens), Christine Goldberg's type monograph (1997), the author's article (Orangen: Die drei O. [AT 408]), published in Enzyklopädie des Märchens and the nearly 200 studied text variants categorised under type AT 408 from the Archives of Enzyklopädie des Märchens (except re-editions and translations and texts erroneously categorised under this type).

\section{Comments}

${ }^{1}$ It resulted in a detailed variant analysis (Anderson s.a.), which formed a part of his unfinished study.

${ }^{2}$ From: Anderson, Walter: Die zwei chinesischen Mischredaktionen. Manuscript in the Göttingen Archives of Enzyklopädie des Märchens, $1 \mathrm{f}$.

${ }^{3}$ Perhaps due to Anderson's influence, Goldberg (1997: 69) equals the disappearance of the girl, hardly unusual among magical creatures, with her death.

${ }^{4}$ E.g.

Koch, ach Koch, sage mir nur: Cook, o Cook, please tell me

Was macht der König und die schwarze Figur?

What are the King and the Black Figure doing?

the original:

Ca, ca, ca, come ze la passe lu fijje de lu rré che la B. S. [bbrutta Saracine]?

$\mathrm{Coo}, \mathrm{coo}, \mathrm{coo}$, how are the Prince and the ugly Saracen woman?

${ }^{5}$ Analogous introduction is characteristic of the folk tale "Faithful John" (AT 516); the longing for a woman, who is as red as blood and as white as snow, marble, etc. occurs often in the introduction of the Italian variants of "The Three Oranges", e.g. in Basile.

${ }^{6}$ Cf. e.g. the anonymous French fairy tale Incarnat, blanc et noir (1719), which is related to a certain number of Hindu variants by an inexplicable 
link; Bozhena Nèmcová's (1845) variant from the Slovack narrative tradition; the archaic Spanish verse epic Leyenda de las tres toronjas de amor by Agustín Durán (1856).

${ }^{7}$ Here Anderson's argumentation about narrative logic has reached to the extent where he postulates that the orange girl had to be naked because otherwise the hero would recognise the (black, pimpled, crook-nosed, oneeyed) impostor woman by her clothes [!].

Translation into English through the Estonian language (Estonian translation by Reet Hiiemäe).

\section{References}

Anderson, Walter s.a. Die drei Orangen. Manuscript in the Göttingen Archives of Enzyklopädie des Märchens.

Anderson, Walter 1959. Le conte des Trois Oranges. Actas do Colóquio de Estudos Etnográficos “Dr. José Leite de Vasconcelos" I: Promovida pela Junta_de Província do Douro Litoral (de 18 a 23 de Junho de 1958). Porto: Impr. Portuguesa, pp. 1-6.

Assaf, Ursula \& Assaf, Yussuf 1978. Märchen aus dem Libanon. Die Märchen der Weltliteratur. Düsseldorf \& Köln: Diederichs.

Boulenger, Jacques 1935. Les Contes de ma cuisinière. La Renaissance de la Nouvelle. Paris: Gallimard.

Camarena Laucirica, Julio 1984. Cuentos tradicionales: Recopilados en la provincia de Ciudad Real. [s. l.]

Eberhard, Wolfram 1951. The Girl that Became a Bird. A Comparative Study. Fischel, Walter Joseph (ed.). Semitic and Oriental Studies: A volume presented to William Popper on the occasion of his seventy-fifth birthday, october 29, 1949. University of California publications in semitic philology

11. Berkeley [u.a.]: University of California Press, pp. 79-86.

Espinosa, Aurelio Macedonio Hijo 1946. Cuentos populares de Castilla. Colección austral 645. Buenos Aires: Espasa-Calpe.

Fabrizi, Angelo 1972. Carlo Gozzi e la tradizione popolare (a proposito de "L'amore delle tre melarance"). Italianistica: Rivista di letteratura italiana 7. Milano: Marzorati, pp. 336-345.

Finamore, Gennaro 1885. Tradizioni popolari abruzzesi 1: Novelle \& 2. Lanciano.

Goldberg, Christine 1997. The Tale of the Three Oranges. Folklore Fellows Communications 117: 263. Helsinki: Suomalainen Tiedeakatemia.

Jech, Jaromír 1961. Tschechische Volksmärchen. Volksmärchen. Berlin: Rütten \& Loening = 1984. 2., vollst. bearb. u. erw. Aufl., Volksmärchen. Berlin: Akademie-Verlag. 
Jiménez Romero, Alfonso \& Pérez Bautista, Melchor (eds.) 1990. La flor de la florentena: Cuentos tradicionales. [Sevilla]: Fundación Machado.

Karlinger, Felix (ed.) 1973. Italienische Volksmärchen. Die Märchen der Weltliteratur. Düsseldorf \& Cologne: Diederichs.

Larrea Palacín, Arcadio de 1952. Cuentos populares de los judíos del norte de Marruecos I. Tetuán: Editora Marroquí.

Llano Roza de Ampudia, Aurelio de 1925. Cuentos asturianos. Madrid: Centro de Estudios Historicos.

Lüthi, Max (ed.) 1974. Das europäische Volksmärchen: Form und Wesen. 4., erw. Aufl. Uni-Taschenbücher 312. München: Francke.

Mason, J. Alden 1925. Porto Rican Folk-Lore; Folk-Tales. Espinosa, Aurelio M. (ed.). Journal of American Folk-Lore 38, pp. 507-618: Linda niña, $545 \mathrm{ff}$.

Megas, Georgios A. 1965. Griechische Volksmärchen. Die Märchen der Weltliteratur. Düsseldorf \& Cologne: Diederichs.

Sánchez Pérez, José A. 1942. Cien cuentos populares. Coleccion literaria ASETA 7. Madrid: Ed. Saeta.

Seignolle, Claude 1946. Contes populaires de Guyenne 1: Contes merveilleux et romanesques: Contes animaux. Collection documentaire de folklore de tous les pays. Paris: G.-P. Maisonneuve.

Shojaei Kawan, Christine 1996. Lippi, Lorenzo. Ranke, Kurt \& Brednich, Rolf et al. (eds.) Enzyklopädie des Märchens: Handwörterbuch zur historischen und vergleichenden Erzählforschung 8: Klerus - Maggio. Berlin \& New York: de Gruyter, pp. 1093-1097.

Shojaei Kawan, Christine. Orangen: Die drei O. [AT 408]. Ranke, Kurt $\&$ Brednich, Rolf et al. (eds.) Enzyklopädie des Märchens: Handwörterbuch zur historischen und vergleichenden Erzählforschung 10: NibelungenliedProzessmotive. Berlin \& New York: de Gruyter, pp. 346-355. 